\title{
Mother's Knowledge In The First Management Of Child Fever in North Demangan
}

\author{
Eka Sarofah Ningsih*, Mise \\ Lamongan Islamic University, Indonesia \\ *ekasnhp@gmail.com
}

\begin{abstract}
Maintaining children's health is a special concern when the seasons change, which is usually accompanied by the development of various diseases. The condition of the child from healthy to sick causes the body to react to increase the temperature which is called fever (hyperthermia). Fever is the body's normal response to infection. Infection is a condition where microorganisms enter the body, which can be viruses, bacteria, parasites, or fungi. Fever in children is generally caused by a viral infection (Setiawati, 2010). This research is a quantitative research with analytic research type and with cross sectional approach method. with a sample size of 50 respondents. Knowledge can be influenced by educational factors, where it is hoped that with higher education the knowledge will be wider. Respondents' understanding of how to determine fever treatment was good enough. Almost all respondents $(80 \%)$ are aware that measuring body temperature using a thermometer is the most accurate way to find out a child's body temperature. Measuring body temperature using a thermometer is more accurate than using hand touching because hand touch is subjective and does not accurately assess body temperature.
\end{abstract}

Keywords: Knowledge, Treatment first, Fever in Children 


\section{STRADA Jurnal Ilmiah Kesehatan}

DOI: $10.30994 /$ sjik.v9i2.492

ISSN: 2252-3847 (print); 2614-350X (online)

Vol.9 No.2 November 2020 Page.1489-1494

\section{BACKGROUND}

Child health problems are one of the main problems in the health sector that currently occurs in Indonesia. The degree of children's health reflects the nation's health status, because children as the nation's next generation have abilities that can be developed in continuing the nation's development. Based on these reasons, children's health problems are prioritized in planning or structuring national development (Hidayat, 2012). At present, health development in Indonesia is recognized as relatively successful, but the success achieved has not been able to completely solve health problems (Arisandi, 2012). Maintaining children's health is a special concern when the seasons change, which is usually accompanied by the development of various diseases. The condition of the child from healthy to sick causes the body to react to increase the temperature called fever (hyperthermia).

Fever (hyperthermia) is a condition where the body temperature is higher than usual, and is a symptom of a disease (Maryunani, 2010). Fever is the body's normal response to infection. Infection is a condition where microorganisms enter the body, which can be viruses, bacteria, parasites, or fungi. Lubis, dalam Cahyaningrum, ( 2017) said that fever in children is generally caused by a viral infection. Fever can also be caused by exposure to excessive heat (overhating), dehydration or lack of fluids, allergies or due to immune system disorders. Today, fever is considered a common sick condition. Fever is also a condition that is often suffered by children. Almost every child must have felt a fever. Basically, there are two fever conditions that require different management. The first is fever which should not be lowered too quickly because it is a response to a mild infection which is self-limited. The second is fever which requires immediate management as it is a sign of serious and life-threatening infections such as pneumonia, meningitis, and sepsis. Therefore, understanding the proper management of fever in children is important to understand. Handling of fever in children really depends on the role of parents, especially mothers.

Mothers are an integral part of household management, which tenderness is needed to care for children skillfully in order to grow up healthy. A mother who knows about fever and has a good attitude in providing care can determine the best fever management for her child. Reducing or controlling and controlling fever in children can be done in various ways, including by administering antipyretics (pharmacologic). Some research evidence shows the positive effects of fever, namely triggering an increase in the number of leukocytes and increasing the function of interferon which helps leukocytes fight microorganisms. Negative effects of fever that can harm children include dehydration, lack of oxygen, neurological damage, and febrile convulsions.

Several previous studies have shown that there is some kind of knowledge between parents or mothers about fever in children. A study conducted by Dawood et al in Malaysia, shows that parental knowledge includes knowledge of fever drugs, drug side effects, and drug dosage forms that work well for children with fever. Meanwhile, research conducted by Youssef et al in Saudi Arabia revealed that parents' knowledge about fever includes knowledge of fever temperature that does not need to be treated and temperature limits to provide therapy. Research conducted by Kazeem et al in Nigeria shows that what is meant by maternal knowledge about fever is knowledge about fever temperature, causes of fever, fever characteristics, the effects of fever progression, and how to determine if a child has fever. From these various studies, it can be seen that the knowledge of mothers about fever in each country varies widely. Especially in Indonesia, every place is different. Mother's different knowledge will result in the management of fever in different children. 


\section{STRADA Jurnal Ilmiah Kesehatan}

DOI: $10.30994 /$ sjik.v9i2.492

ISSN: 2252-3847 (print); 2614-350X (online)

Vol.9 No.2 November 2020 Page.1489-1494

The level of knowledge of mothers about fever in Indonesia also varies widely considering that this is influenced by many factors.

Based on the theory and phenomena that occur in North Demangan, the researcher intends to examine the knowledge of mothers about the first treatment of fever in children by answering research questions on how to describe the level of mother's knowledge regarding the first treatment of fever in children in the North Demangan area.

\section{METHODS}

This research is a quantitative research with analytic research type and cross sectional approach method. The research was conducted on 9 July - 13 July 2020 using accidental sampling technique, namely by taking respondents who happened to be there or were available at the research site, with a total sample of 50 respondents. The measurement instrument used was a questionnaire by giving questions to respondents and analyzed using statistical tests, namely the Spearman Rank.

\section{RESULTS}

Table 1. Frequency distribution of mothers by age, education, occupation, and maternal income in North Demangan in 2020. $(n=50)$

\begin{tabular}{lll}
\hline Mother characteristics & Frequency (n) & Percentage (\%) \\
\hline Age (Years) & 7 & 14 \\
Late Youth & 27 & 54 \\
Early Adult & 16 & 32 \\
Late Adult & & \\
\hline Education & 16 & 32 \\
High & 18 & 36 \\
Intermediate & 16 & 32 \\
Basic & & \\
\hline Profession & 36 & 72 \\
Does not work & 14 & 28 \\
Work & & \\
\hline Income & 5 & 10 \\
Very high & 6 & 78 \\
Moderate & 39 & \\
Low & & \\
\end{tabular}

Based on table 1, it is known that most of the mother's age was early adulthood (26-35 years) as many as 27 mothers (54\%). Based on the level of education, most of the mothers' education was secondary (SMA) as many as 18 mothers (36\%). Based on occupation, most of the mothers did not work as much as 36 mothers (72\%), and based on income, most mothers had low income as many as 39 mothers $(78 \%)$.

Table 2 Distribution of frequency of mothers according to knowledge of mothers about fever in children. $(n=50)$.

\begin{tabular}{lcc}
\hline Variable & Frequency $(\mathrm{n})$ & Percentage $(\%)$ \\
\hline Knowledge & 40 & 80 \\
Well & 40 & \\
\hline
\end{tabular}




\section{STRADA Jurnal Ilmiah Kesehatan}

DOI: $10.30994 /$ sjik.v9i2.492

ISSN: 2252-3847 (print); 2614-350X (online)

Vol.9 No.2 November 2020 Page.1489-1494

\begin{tabular}{lcc}
\hline Enough & 8 & 16 \\
Less & 2 & 4 \\
\hline Total & 50 & 100 \\
\hline
\end{tabular}

Based on table 2, it is known that most of the mothers' knowledge about fever is in a good category as many as 40 mothers (80\%). The results of the study were supported by research conducted by Izah, in (2013) on the relationship between maternal knowledge and Dengue Hemorrhagic Fever prevention behavior in Sendangmulyo Village in 2013, that most of the mother's knowledge level about the prevention of dengue hemorrhagic fever was in the good category, namely 36 mothers $(52,8 \%)$

\section{DISCUSSION}

Knowledge is the result of human senses, or the result of a person's knowing of an object through his senses. Most of one's knowledge is acquired through the sense of hearing (ears) and the sense of sight (eyes). Knowledge can be influenced by educational factors, knowledge is very closely related to education, where it is hoped that with higher education, people will have wider knowledge. Education is needed to obtain information, for example, knowledge of mothers about fever in children under five. In general, the higher a person's education, the easier it is to receive information.

Another research that supports Pujiyanti's research, year (2010), which is significant between knowledge, attitudes, and behavior of housewives with the prevention of dengue hemorrhagic fever in Kutowinangun, Salatiga, with a p-value of 0,206. Fever handling behavior in children under five is not only influenced by the knowledge factor but there are several factors that influence behavior. The factors that influence behavior are predisposing factors, which include knowledge and attitudes towards health, traditions and beliefs, adopted value systems, education level, social and economic levels. Enabling factors, including the availability of facilities and infrastructure or health facilities, and personal control are a person's belief that he is capable of influencing unwanted events. Education level affects mother's behavior in handling fever. Predisposing factors that influence behavior, one of which is the level of education.

Rosnah, in Neni (2016) states that maternal education affects the behavior of complementary feeding at the Perumnas Public Health Center, Kadia District, Kendari City. Mother's belief in handling fever can also affect mother's behavior, based on the answers to the behavior questionnaire, that as many as 10 mothers answered "yes" to the statement "I use traditional medicine because it is safer to treat fever in children". Trust is often obtained from parents, grandparents, someone accepts that belief based on belief and without any prior proof. Behavior is also influenced by factors that come from within and from outside the individual, one of these factors is the environment. Behavior is defined as an action or reaction of a person to their environment. Behavior when a child has a fever that is carried out by the mother because of the stimulation to take action to treat fever in children under five, such as wearing thin clothes, compressing with warm water, giving lots of drinking, and giving antipyretic drugs.

Respondents' understanding of how to determine fever is good enough. Almost all respondents $(80 \%)$ are aware that measuring body temperature using a thermometer is the most accurate way to find out a child's body temperature. Measuring body temperature using a thermometer is more accurate than using hand touching because hand touch is subjective and does not accurately assess body temperature. Measuring the high fever using a thermometer can be done in several places, including rectal, oral, axilla, and 


\section{STRADA Jurnal Ilmiah Kesehatan}

DOI: $10.30994 /$ sjik.v9i2.492

ISSN: 2252-3847 (print); 2614-350X (online)

Vol.9 No.2 November 2020 Page.1489-1494

tympanic. This seems to be poorly understood by respondents, most of whom said that the thermometer can only measure body temperature when it is placed on the axilla and is considered the most accurate. Only $16 \%$ of respondents said that body temperature measurements can be taken rectally and orally. Measurement of axillary temperature is easy to do so it is common practice, but only describes the body peripheral temperature which is strongly influenced by vasoconstriction of blood vessels and sweat so it is less accurate when compared to rectally.

Respondents' knowledge about the continued impact of fever shows that $80 \%$ of respondents know that fever in children can cause febrile seizures so that it needs to be watched out. Regarding various other adverse effects of fever, most respondents agreed that fever can cause dehydration (56.8\%), loss of consciousness (50\%), and nerve damage $(56.8 \%)$. The knowledge of respondents about lack of oxygen and coma as a form of the effects of fever is only understood by a small number of respondents. This study shows that the respondent's level of knowledge is lower than the two previous studies. Previous research conducted by Youssef et al, found that $96 \%$ of parent respondents stated that the main complication of fever was the occurrence of febrile seizures. Another study, namely research conducted by Kazeem, obtained results that were not much different where the majority of mother respondents stated that fever can cause febrile seizures $(75 \%)$, death $(31 \%)$, and brain damage (31\%).

Then based on the data analysis, it can be seen that the level of education and family income does not have a significant effect on the relationship between the level of knowledge of mothers about fever and the management of fever in children. This shows that mothers with a high level of education cannot be used as a definite benchmark for having a good level of knowledge about fever and managing child fever as well. This finding may be because mothers with high levels of education generally spend more time on work (careers) so that time for caring for their children is more limited and may rely a lot on childcare to their parents or helpers.

The limitation of this study is that it uses respondent mothers whose children are often sick with fever symptoms and do not involve respondents from the general population. This causes the interpretation of the research results to be limited to mothers whose children often experience fever. Further research involving the general population with a larger sample size is needed to find out more about the relationship between the level of maternal knowledge about fever with the management of child fever and the factors that influence it.

\section{CONCLUSION}

There is a significant relationship between the level of knowledge of mothers about fever and the first treatment performed on children. Mother's knowledge about fever in children in North Demangan can also be said to be quite good. The higher the level of mother's knowledge about fever, the better the management of fever in children. Mothers with a low level of knowledge were 7 times more likely to have poor management of child fever than mothers with a high level of knowledge. Then suggestion from the author to mothers wherever they are which should add basic insight about diseases in children, especially those that are frequent and familiar is fever.

\section{REFERENCES}

Arisandi, Yohana dan Andriani, Yofita. 2012. Therapy Herbal Pengobatan Berbagai Penyakit. Cet 6. Jakarta: Eska Media. 


\section{STRADA Jurnal Ilmiah Kesehatan}

DOI: $10.30994 /$ sjik.v9i2.492

ISSN: 2252-3847 (print); 2614-350X (online)

Vol.9 No.2 November 2020 Page.1489-1494

Cahyaningrum, Etika. 2017. Perbedaan Suhu tubuh anak demam sebelum dan setelah kompres bawang merah. Jurnal ilmiah ilmu-ilmu kesehatan. Vol. 15. No. 02.

Hidayat, A. Aziz Alimul. 2012. Metode Penelitian Kebidanan Teknik Analisis Data. Edisi Pertama. Jakarta: Salemba Medika.

Izah, S. N. (2013). Hubungan Pengetahuan Ibu Dengan Perilaku Pencegahan Demam Berdarah Dengue di RW XI Kelurahan Sendangmulyo Kecamatan Tembalang. Skripsi. Universitas Muhammadiyah Semarang

Maryunani, Anik. 2010. Ilmu Kesehatan Anak Dalam Kebidanan. Jakarta: TIM

Neni, Harianti. 2016. Hubungan tingkat pengetahuan ibu tentang demam dengan perilaku ibu dalam penanganan demam pada anak balita di puskesmas depok 1 Sleman Yogyakarta.

Pujiyanti, A. (2010). Hubungan Pengetahuan, Sikap, Dengan Perilaku Ibu Rumah Tangga Dengan Pencegahan Demam Berdarah Dengue Dikelurahan Kutowinangun Salatgia

Setiawati, Tia. 2010. Pengaruh Tepid Sponge. Jakarta: Fakultas Ilmu Kedokteran Universitas Indonesia. 